\title{
INTERNATIONAL JOURNAL OF ASTROBIOLOGY
}

journals.cambridge.org/ija
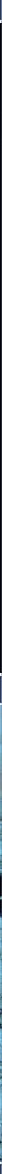


\title{
INTERNATIONAL JOURNAL OF ASTROBIOLOGY
}

\author{
Editor \\ Dr Rocco Mancinelli, SETI Institute, USA
}

\begin{abstract}
Editorial Board
Dr John Brucato, Observatory Arcetri, Italy

Professor Mark J Burchell, University of Kent at Canterbury, UK

Professor Ed Cloutis, University of Winnipeg, Canada

Professor Charles Cockell, The Open University, UK

Dr Claire Cousins, University College London, UK

Professor H. G. M. Edwards, University of Bradford, UK

Professor Pascale Ehrenfreund, University of Leiden,

The Netherlands

Professor Alex Ellery, Carleton University, Canada

Professor Bernard Foing, ESA-ESTEC, The Netherlands

Professor Jesus Martinez Frias, Centro de Astrobiologia,

Madrid, Spain

Dr Beda Anton Hofmann, Bern Natural History Museum, Switzerland

Professor Nils Holm, Stockholm University, Sweden

Dr Gerda Horneck, DLR FF-ME, Germany

Dr Jonathan A. Horner, University of New South Wales,

Australia

Professor Jan Jehlicka, Institute of Mineralogy and

Geochemistry, Prague, Czech Republic

Professor Barrie Jones, The Open University, UK

Dr Inge Ten Kate, Utecht University, USA

Dr Helmut Lammer, Space Research Institute, Austria

Dr Natuschka Lee, TU München, Germany

Dr Zita Martins, Imperial College, London, UK

Dr Chris McKay, NASA Ames Research Center, USA

Dr Simon Mitton, University of Cambridge, UK

Dr Kenneth Nealson, University of Southern California/JPL, USA

Dr Elke Pilat-Lohinger, University of Vienna, Austria

Dr Lynn Rothschild, NASA Ames Research Center, USA

Dr Christian Schröder, University of Tübingen, Germany

Professor Mark A. Sephton, Imperial College, London, UK

Dr Henry Sun, Arizona State University, USA

Professor Peter Vandenabeele, Ghent University,

Belgium

Professor Lyle Whyte, McGill University
\end{abstract}

\section{Founding Editor}

Dr David Wynn-Williams (1946-2002)

\section{SUBSCRIPTIONS}

International Journal of Astrobiology (ISSN 1473-5504), electronic 1475-3006 is published four times a year (one volume per annum) in January, April, July, and October. The 2012 subscription price (excluding VAT) of a volume, which includes print and electronic access, is $£ 272$ (US $\$ 504$ in USA, Canada and Mexico). The electronic-only price available to institutional subscribers is $£ 230$ (US \$412 in USA, Canada and Mexico). For individuals ordering direct from the publisher and certifying that the journal is for their personal use, the subscription price for print plus electronic access is $£ 88$ (US \$160 in USA, Canada and Mexico).

Orders, which must be accompanied by payment, may be sent to any bookseller, subscription agent or direct to the publisher: Cambridge University Press, The Edinburgh Building, Shaftesbury Road, Cambridge CB2 8RU, UK; or in the USA, Canada and Mexico: Cambridge University Press, Journals Fulfillment Department, 100 Brook Hill Drive, West Nyack, New York 10994-2133. EU subscribers (outside the UK) who are not registered for VAT should add VAT at their country's rate. VAT registered members should provide their VAT registration number. Japanese prices for institutions (including ASP delivery) are available from Kinokuniya Company Ltd, P.O. Box 55, Chitose, Tokyo 156, Japan. Prices include delivery by air. Postmaster: send address changes in USA, Canada and Mexico to: International Journal of Astrobiology, Cambridge University Press, 100 Brook Hill
Drive, West Nyack, New York 10994-2133. Claims for missing issues should be made immediately on receipt of the subsequent issue.

\section{ADVERTISING}

Apply to the Publisher Cambridge University Press (address above). Address enquiries to the Advertising Promoter.

\section{COPYRIGHT AND PERMISSIONS}

This journal is registered with the Copyright Clearance Center, 222 Rosewood Drive, Danvers, MA 01923, USA. Organizations in the USA who are also registered with C.C.C. may therefore photocopy material (beyond the limits permitted by Section 107 and 108 of U.S. Copyright law) subject to payment to C.C.C. of the per-copy fee of $\$ 16.00$. This consent does not extend to multiple copying for promotional or commercial purposes. Code 1473-5504/2011 \$16.00. ISI Tear Sheet Service, 3501 Market Street, Philadelphia, PA 19104, USA, is authorised to supply single photocopies of separate articles for private use only. Organizations authorised by the UK Copyright Licensing Agency may also copy material subject to the usual conditions. For all other use, permission should be sought from Cambridge University Press.

No part of this publication may otherwise be reproduced, stored or distributed by any means without permission in writing from Cambridge University Press, acting for the copyright holder.

Copyright (C) 2012 Cambridge University Press

\section{ELECTRONIC ACCESS}

This journal is included in the Cambridge Journals Online service which can be found at: journals.cambridge.org For further information on other Press titles access uk.cambridge.org or us.cambridge.org

This journal issue has been printed on FSC-certified paper and cover board. FSC is an independent, nongovernmental, not-for-profit organization established to promote the responsible management of the world's forests. Please see www.fsc.org for information. 